東洋医学々西洋医学を利用する患者の疾病行動分析 金 松賢 ${ }^{*}$ 金 命鎬** 南 銀祐 $* * *$

\title{
An Analysis of Illness-Behavior of Patients between Oriental Medicine and Western Medicine
}

\section{Song Hhyun KIM*, Myung Ho KIM* and Eun Woo NAM*}

Health-related behavior and disease patterns of patients who were cured by either Oriental or Western Medicine were analyzed by a questionnaire survey data conducted on 455 patients in Seoul, Korea, October 1991. These objects were patients who consisted of 218 patients visiting with Oriental Hospitals $(\mathrm{POH})$ and 237 patients in Western hospitals (PWH). The disease patterns of these two groups were significantly different. Diseases of patients who visited with $\mathrm{POH}$ were mainly diseases of the circulatory system (70.97\%) and diseases of musculoskeletal system and connective tissue (11.14\%), whereas diseases of PWH patients were occupied by diseases of the digestive system (10.35\%), injury and poisoning fractures $(11.67 \%)$, and also the circulatory system (10.88\%) in the codes of ICD-9. As to comparisons in prevalence of diseases between $\mathrm{POH}$ and $\mathrm{PWH}$, transient ischemic attack was prevalent in $\mathrm{POH}$, and diabetes mellitus was dominant in $\mathrm{PWH}$, even though cerebral embolism and hemorrhage were common in both. However, female and elderly patients visited more easily with $\mathrm{POH}$ than male and younger generations. It has been made clear that the threshold of visiting $\mathrm{POH}$ was independent from sociocultural attributes of residence, income, education, type of health insurance and religion. When this survey questioned also whether Korean Government should promote the integration of Oriental and Western Medicine in the medical policy, $67.8 \%$ of the POH patients and $54.9 \%$ of the PWH patients respectively agreed it.

\section{I 緒言}

韓国の伝統医学（traditional medicine）は古朝 鮮時代から始まり, 原始医療という行為で続けら れてきたが，人知の発達と共に漸次合理的な形態 に定着し, 高句麗の平原王 5 年 (A.D. 561) 中国
の江南で建国した吳の知聰が内外伝, 薬書, 明堂 図など漢薬書籍164巻をもって高句麗を経て日本 に土着する過程で影響をらけたものと考えられて いる（金，1986）。

このような伝統医学が韓国では，韓方医療又は 韓方医学 (oriental medicine) として理解されて

* 順和堂韓方医院 (京畿道, 韓国)

** 延世大学校医科大学名挙教授 (ソウル, 韓国)

*** 高神大学保健科学研究所長 (釜山, 韓国)

* Sun Wha Dang Oriental Clinic, Kyunggi-Do, Korea

** Emeritus Professor, College of Medicine, Yonsei University, Korea

*** Director, Institute of Health Science, Koshin University, Pusan, Korea 
きたが，1960年代以後にはこれに対する国際的関 心も高まり，鍼術と韓方医療が現今の科学的な現 代医療（modern medicine）に対する一種の補完 的な位置であることに留まらず，保健医療体系の 一つの新しい形態として発展して扣り（金と柳， 1988）ここような韓方医療は都市に打ける家計の 医療費支出構成において全体の $20 \%$ を占めるよう になった（朴, 1979, 李ら, 1984).

韓国は東洋医学（中国では中医学，日本では皇 漢医学, 漢方医学または中国医学, 蒙古では蒙医 学, 北朝鮮は東医学と称する）にもとづく韓方医 療と, 西洋医学を基礎とした洋方医療を共に採用 して二元化した医療制度を採っている。これに関 係する色々な煩雑さが生じたため, 韓国政府は, 最近, 西洋医学と東洋医学を一元化するための計 画を推進する立場とをとっている（保健社会部, 1991).

現在, 韓国では韓医師（東洋医学取扱医師）を 養成する大学は 9 校, 学生定員は720名であり, 医 師（西洋医学取扱医師）を養成する大学は32校で 学生定員は2,880名を策定している（保健社会部, 1990).

韓国の医療制度は東洋医学の運営が二元化して いる点で多くの問題を内包しているが，このうち 東洋医学に関する根本的な問題は西洋医学に比し て科学性を欠いている点である。それは実験に基 づいた帰納法的研究手段が手薄であって, 演繹的 な現象把握に依存しているためであるが，他面， 西洋医学に比して東洋医学には副作用が少ないと いう長所もある（砂原，1990a）。な拈，東洋医学 が応急処置, 外科的処理, 伝染病の管理等に弱点 があり, 病気の予後推定も困難であるという短所 があるが，西洋医学にも細分化し過ぎていて全体 性を欠くという短所があり(金, 1988)，二つの医 学体系の長所を綜合することができるならば，人 類にとって望ましい。このようなことから東洋医 学と西洋医学を別個の学問体系のままで放置して おくことは不合理であるとの指摘（李ら，1985） は当然といえる。

しかし, 韓国の東洋医学と西洋医学の両体系を
比較してみると，いくつかの例外が除くと，他は ほとんど異なって扣り，互に独立した医療体系で 運営されている。このような, 人体と疾病につい て学問体系が二つあるという状態は統合されるべ きであるという歴史的展望が韓国では根強いこと にもなる(南ら，1991）。日本の場合，その重要性 は小さいが，東洋医学を愛用する患者がいること はもちろん西洋医学の医師免許を得た医師しかい ないが, 漢方薬と鍼等の患者の疾患（例，感冒， 更年期障害，胃炎等)によって使い分けている(砂 原，1990b，森谷，1978）。な拈，中国の医師は， Barefoot doctor の場合は当然のことながら, 西 洋医学の教育と東洋医学 (中医学) 教育の課程で, 533個の漢薬と鍼，众などの教育も実施している (Quinn, 1973).特に中国は中国の伝統医学に西洋 医学が積極的に結合して中医学の発展を図ってい る(楢木, 1991)。北朝鮮は東洋医学 (東医学) に 大きな比重を置いており，北朝鮮政府はこれを政 策的に奨励している，特に，多くの医療機関で東 医学の診療科を設置して運営中であり，1958年度 から医学科学院傘下に東医学研究所を設置してこ の分野を発展させている。このような東洋医学の 利用率は $50 \%$ 以上で大部分の疾患治療に使用され ているという報告がある（南ら，1988）.

上記のいくつかの指摘に見られるように，韓国 は国民の受療システムが二元化している数少ない 国家で，患者は東洋医学々西洋医学を自由選択し ている実情である。最近15年間でも東洋医学の利 用と関連した研究が数篇ある(李, 1978 ; 李, 1979, 蔡, 1979, 洪, 1979, 鄭, 1982, 趙, 1990, 李他, 1991, 韓国消費者保護院調査部, 1991, 南他1991). また西洋医学の利用に関連する研究(金他, 1980, 崔, 1988，金，1991，趨，1982，李他，1984，裴， 1985, 黄, 1986, 韓他, 1986, 柳他, 1987, 宋, 1988，金，1990）が多数ある。しかし，東洋医学 と西洋医学を利用する患者の受注行為を比較分析 した研究は殆ど無い。本研究では同じ都市に所在 する大学の病院（医科大学拈よび韓医科大学の付 属病院）の患者などの疾病形態 (disease pattern) と受療行為を比較分析してこれら両医療システム 
の統合又は一元化の基礎資料を提供することを目 的としている。本研究の具体的な目的と内容は次 の通りである。

1. 東洋医学利用者と西洋医学利用者の疾病形 態を比較する。

2. 東洋医学利用者々西洋医学利用者の受療行 動を分析する，具体的な分析内容は次の通りであ る。

1) 東洋医学利用者と西洋医学利用者の特性を 比較する。

2) 東洋医学利用者之西洋医学利用者の受療行 動の差異を分析する。

3）東洋医学と西洋医学統合に対する態度を比 較する。

\section{II 対象と方法}

1. 研究の対象と調査方法

本研究は東洋医学を利用する患者と西洋医学を 利用する患者の受療行動と疾病状況の差異を分析 したものである。そのために韓国で唯一の東洋医 学と西洋医学が共存する（大韓病院協会, 1991) 医科大学附属病院 (College of Oriental Medicine：339病床）の外来・入院患者を対象に調査し た. 東洋医学の患者と西洋医学の患者間の疾病形 態を比較するために対象病院における 3 年間の診 療記録簿の統計資料を分析した。なお，受療行動 を比較するために質問票による調査を実施した。

\section{2. 研究の方法}

受療行動と関連する内容を調べるためには実際 の資料を比較検討しなければならない(裴, 1985). これと関連した研究動向には疾病行動研究（Illness-Behavior Study）と多変量解析による分析 (Multivariate Analysis Study) がある (Mechanic, 1978).

このうち疾病行動研究は社会文化的要因, 心理 的要因, 医療体系の特性などが一般人の疾病に対 する定義と医療利用に重要な影響を及济すと考兄 られており，多変量解析により理論的に深層的に 迫ることができるという理由で，比較的に小さい 小標本を調査資料として利用することが多い。
本研究は疾病行動論的研究方法を基本研究模型 を設定して研究を遂行した。疾病形態を比較する ために対象病院の診療記録簿から資料を収集して 分析した。な拉，受療行動の分析のためには質問 票調査を実施した。質問票調査の対象は来院患者 の内から482名を層化無作為抽出した。 そのうち調 査結果の分析に使用された応答者の総数は455名 (入院174名，外来281名)であった。 またその内で 東洋医学の利用患者は218名であり, 西洋医学患者 は237名であった。調査には，患者への接近が容易 な看護学科 3 学年学生の病棟実習生 8 名が担当助 手の指導下，1991年 9 月 3 日から10月 6 日までの 期間中に面接聞き取り調査した。

今回の質問紙では医療機関を利用した患者の東 洋医学々西洋医学に対する受療行動を分析したの であるが，その際患者の年齢，教育水準，世帯所 得，家族数などをいくつかの範疇に分けた。

本調査の母集団は大都市に位置する医科大学々 韓医科大学の附属病院の患者であり, 標本抽出単 位は外来と入院にわけて層化無作為抽出 （stratified random sampling）した。標本が大き ければ大きいほど標本誤差は小さくなるが (Aviva, 1978), 本研究の標本の大きさは482名で あり, 質問票調查の結果, 27 名は内容の記入等が 不十分で分析から除去し, 最終的に 455 名を分析し た.

分析に使用した変数が全部名目变数であるので 頻度分析と交叉分析を利用した。統計分析は $\chi^{2}$ 一検定によって統計的検証の有意水準は $5 \%$ 末満 とした.このような受療行動の調査を行う理由は, 患者の医療アクセスが疾病と健康に対する意識と 行動, 社会文化的要因等々関連しているからであ る(文昌真，1990)。これらの医療機関に対する患 者の受療行動を分析することにより東洋医学と西 洋医学の特性を知ることができるからである。 た疾病の形態分析を行ら理由は，国民の疾病構造 之受療行動がこの二つの医療体系の利用状況に具 体的に表出されるからである。ささらに分析の結果 を通して，地域住民の医療需要に応える望ましい 保健医療体系の開発が可能になるためである. 


\section{III 結果}

1. 東洋医学と西洋医学の利用患者の疾病構造 の分析

1）国際疾病分類による入院患者の疾病構造

ICD-9分類法（WHO，1975）を参考にして入院 患者の疾病構造を17大分類にわけて比較した結 果, 東洋医学は循環系疾患が $70.97 \%$, 次に筇骨格 系・結合組織疾患が $11.14 \%$, 内分泌栄養・代謝免 疫疾患が2.9\%, 西洋医学系病院は損傷及び中毒が $11.67 \%$, 循環系疾患が $10.88 \%$ ，そして消化系疾 患が10.35\%である（表 1).

\section{2）多発性疾患の順位比較}

東洋医学系と西洋医学系の入院患者の多発性疾 患を比較した結果, 東洋医学系患者は脳梗塞 (50.44\%), 脳出血 (14.34\%), 急性脳血管障害 (10.01\%) の順であり，この 3 疾患が74\%程度で ある。西洋医学系患者は脳梗塞 (11.92\%) 糖症病 (9.02\%), 脳出血 (8.72\%) 等である（表 2 ).

2. 東洋医学々西洋医学利用書の医療行動分析
表 1 ICD-9分類法によって東洋医学と西洋医学 入院患者の疾病名の比較

\begin{tabular}{|c|c|c|c|c|}
\hline \multirow{2}{*}{ 疾 病 名 } & \multicolumn{2}{|c|}{ 東洋医学病院 } & \multicolumn{2}{|c|}{ 西洋医学病院 } \\
\hline & 患者数 & $(\%)$ & 患者数 & (\%) \\
\hline 感染性 - 寄生虫症 & 53 & $(0.53)$ & 3,799 & $(5.97)$ \\
\hline 新生物 & 166 & (1.66) & 4,674 & (7.35) \\
\hline $\begin{array}{l}\text { 内分泌・栄養・代謝免 } \\
\text { 疫疾患 }\end{array}$ & 291 & $(2.92)$ & 2,214 & (3.48) \\
\hline 血液・造血器疾患 & 8 & $(0.08)$ & 530 & $(0.83)$ \\
\hline 精神障害 & 295 & $(2.96)$ & 1,686 & (2.65) \\
\hline 神経系・感覚器疾患 & 316 & (3.17) & 3,299 & (5.19) \\
\hline 循環系疾患 & 7,083 & $(70.97)$ & 6,922 & (10.99) \\
\hline 呼吸系疾患 & 69 & $(0.69)$ & 5,764 & (9.06) \\
\hline 消化系疾患 & 247 & $(2.48)$ & 6,584 & (10.35) \\
\hline 泌尿生殖系疾患 & 38 & $(0.38)$ & 3,946 & $(6.20)$ \\
\hline 妊産疾患 & 4 & $(0.04)$ & 6,090 & (9.58) \\
\hline 皮唐・皮下組織疾患 & 133 & (1.33) & 1,141 & (1.79) \\
\hline 筋骨格系・結合組織疾 & 1,143 & (11.14) & 4,426 & (6.96) \\
\hline 先天異常 & 11 & $(0.11)$ & 1,183 & (1.86) \\
\hline 周産期疾患 & 24 & $(0.24)$ & 2,783 & (4.38) \\
\hline $\begin{array}{l}\text { 症状・徵候・診断名不 } \\
\text { 明確の状態 }\end{array}$ & 24 & $(0.24)$ & 1,140 & (1.79) \\
\hline 損傷・中毒 & 76 & $(0.76)$ & 7,421 & $(11.67)$ \\
\hline 計 & 9,981 & $(100.0)$ & 63,602 & $(100.0)$ \\
\hline
\end{tabular}

資料：大韓民国・医療院，診療記録簿統計，1986-1988

表 2 東洋医学と西洋医学利用者の多発性疾患の順位比較

\begin{tabular}{|c|c|c|c|c|}
\hline \multirow{2}{*}{ 順位 } & \multicolumn{2}{|c|}{ 東洋医学系病院 } & \multicolumn{2}{|c|}{ 西洋医学系病院 } \\
\hline & 疾 & 患者数(\%) & 病 & 患者数(\%) \\
\hline 1 & 脳梗塞 & $4,340(50.44)$ & 脳梗塞 & $1,986(11.92)$ \\
\hline 2 & 脳出血 & $1,234(14.34)$ & 糖尿病 & $1,502(9.02)$ \\
\hline 3 & 急性脳血管疾患 & $862(10.01)$ & 脳出血 & $1,452(8.72)$ \\
\hline 4 & 脊椎疾患 & $425(4.94)$ & 春椎疾患 & $1,276(7.66)$ \\
\hline 5 & 春椎分裂と関係する疾患 & $307(3.57)$ & 慢性扁桃, 甲状腺疾患 & $1,221(7.33)$ \\
\hline 6 & 脳血管疾患の後遺症 & $257(2.99)$ & 腸管炎 & $1,212(7.28)$ \\
\hline 7 & 神経性，疾患 & $255(2.96)$ & 正常分婏* & $1,075(6.45)$ \\
\hline 8 & 肥満及び過食 & $187(2.18)$ & 慢性肝疾患及び肝硬変 & $1,052(6.32)$ \\
\hline 9 & 顔面神経麻痷 & $141(1.63)$ & 腎葴及び尿道結石 & $1,045(6.27)$ \\
\hline 10 & $\begin{array}{l}\text { リュウマチ㕍関節炎 } \\
\text { 及び多発性関節症 }\end{array}$ & $123(1.43)$ & 羊膜に関係する疾患 & $950(5.70)$ \\
\hline 11 & 本態性高血圧 & $113(1.31)$ & 肺炎 & $904(5.43)$ \\
\hline 12 & 背部と関連する疾患 & $112(1.31)$ & 急性虫垂突起炎 & $856(5.14)$ \\
\hline 13 & 肝腺及び類似疾患 & $99(1.15)$ & 胃炎及び十二指腸炎 & $770(4.62)$ \\
\hline 14 & 糖尿病 & $80(0.93)$ & 悪性胃癌 & $694(4.17)$ \\
\hline 15 & 慢性肝疾患及び肝硬変 & $70(0.81)$ & $\begin{array}{l}\text { 母性による胎児及び } \\
\text { 胎盤疾患 }\end{array}$ & $662(3.97)$ \\
\hline & 計 & $8,605(100.00)$ & 計 & $16,657(100.00)$ \\
\hline
\end{tabular}

*疾病ではないが, この項目に入れた。

資料：大韓民国医療院，診療記録簿統計，1986-1988 
1）調査対象者の特性比較

調査対象者の特性を諸項目別に観察すると，東 洋医学を利用した者と西洋医学を利用した者全体 の居住地は特別市が $80 \%$ 以上であった（p> 0.05)。性別構成比は東洋医学を利用した者の場 合，男子(33.5\%) より女子 (66.5\%) が多いが, 西洋医学の場合は男子（47.6\%）女子（52.4\%） でほぼ同じ構成比である $(p<0.01)$. 年齢別構成

表 3 特性別利用者の差異比較

\begin{tabular}{|c|c|c|c|}
\hline & 東洋医学 & 西洋医学 & $x^{2}$-test \\
\hline \multicolumn{4}{|l|}{ 居住地別 } \\
\hline 特別市 & 80.3 & 84.1 & \multirow{2}{*}{1.07} \\
\hline 道 & 19.7 & 15.9 & \\
\hline \multicolumn{4}{|l|}{ 別 } \\
\hline 男 & 33.5 & 47.6 & \multirow{2}{*}{$10.35^{* *}$} \\
\hline 女 & 66.5 & 52.4 & \\
\hline \multicolumn{4}{|l|}{ 年 齢 別 } \\
\hline 14以下 & 0.9 & 2.2 & \multirow{4}{*}{$22.43^{* * *}$} \\
\hline $15-44$ & 47.7 & 67.7 & \\
\hline $45-64$ & 39.8 & 25.4 & \\
\hline 65 以上 & 11.6 & 4.7 & \\
\hline \multicolumn{4}{|l|}{ 月所得別\# } \\
\hline 50万 Won 以下 & 23.0 & 25.8 & \multirow{4}{*}{3.15} \\
\hline 50-79万 Won & 27.8 & 25.3 & \\
\hline 80-99万 Won & 20.9 & 26.3 & \\
\hline 100 万 Won 以上 & 28.3 & 22.6 & \\
\hline \multicolumn{4}{|l|}{ 学 歴 別 } \\
\hline 中卒以下 & 18.8 & 15.1 & \multirow{4}{*}{4.35} \\
\hline 高 校 卒 & 37.9 & 47.9 & \\
\hline 大学 卒 & 38.4 & 32.9 & \\
\hline 大学院卒 & 4.9 & 4.1 & \\
\hline \multicolumn{4}{|l|}{ 保険種別 } \\
\hline 共済 & 12.9 & 14.7 & \multirow{5}{*}{6.53} \\
\hline 職場 & 41.0 & 34.9 & \\
\hline 地 域 & 39.5 & 37.1 & \\
\hline 医療保護 & 5.6 & 12.2 & \\
\hline その 他 & 1.0 & 1.3 & \\
\hline \multicolumn{4}{|l|}{ 宗 教 別 } \\
\hline 基督教 & 24.7 & 25.5 & \multirow{6}{*}{3.92} \\
\hline 天主教 & 12.6 & 14.3 & \\
\hline 仏教 & 32.6 & 24.7 & \\
\hline 儒教 & 2.4 & 2.2 & \\
\hline 無 & 26.0 & 31.6 & \\
\hline その他 & 1.9 & 1.6 & \\
\hline $\begin{aligned}{ }^{* *} p & <0.01 \\
{ }^{* * *} p & <0.001\end{aligned}$ & Won & $=¥ 125$ & \\
\hline
\end{tabular}

比は東洋医学を利用した者は15〜44歳（47.7\%）, 45～64歳 (39.8\%)，65歳以上 $(11.6 \%)$ の順であ り，西洋医学を利用した者は15４4歳 (67.7\%), 45～64歳 $(25.4 \%), 65$ 歳以上 $(4.7 \%)$ で年齢が 高ければ高いほど東洋医学を利用する者の割合が 高かった $(\mathrm{p}<0.01)$. 月所得の水準, 学歴, 保険 種別等は差がない $(\mathrm{p}>0.05)$. 宗教については両 医療機関の利用状況には差異がない。しかし，仏 教信者の場合は東洋医学を利用した患者 (32.6\%) が西洋医学を利用した患者よりや〉多い（表 3 ）.

2）来院動機に関する比較

表 4 は東洋医学を利用した者と西洋医学を利用 した者の医療機関を選択する動機を比較したもの である。

東洋医学を利用した者は，医療スタッフが優れ ているから (34.6\%) と，有名だから（31.7\%） とに集中し, 病院のイメージとの関連が高い. 一 方，西洋医学を利用した者の場合は，近いから (22.3\%)，医療施設がよいから $(22.3 \%)$, 有名だ から (15.9\%), 医療スタッフが優れているから (14.5\%)の順で両機関を利用した患者の来院動機 の差異は統計学的に有意である $(\mathrm{p}<0.001)$.

3）経由した医療機関

表 5 は調查対象病院に至る前に患者たちがどの ような医療機関を経由したかについて分析した結 果で, 東洋医学を利用した者の場合は総合病院 (42.7\%)，韓医院 (24.8)，医院 $(15.0 \%)$ ，薬局

表 4 患者の来院理由の比較

\begin{tabular}{|c|c|c|c|}
\hline 来 院 動 機 & 東洋医学 & 西洋医学 & $\chi^{2}$-test \\
\hline 近いから & 5.3 & 22.3 & \\
\hline 医療施設がよいから & 11.5 & 22.3 & \\
\hline 有名たから & 31.7 & 15.9 & \\
\hline 診断が正確だから & 4.8 & 7.7 & \\
\hline $\begin{array}{l}\text { 医療スタッフが優れてい } \\
\text { るから }\end{array}$ & 34.6 & 14.5 & $73.041^{* * *}$ \\
\hline 虚弱だから & 7.7 & 3.6 & \\
\hline $\begin{array}{c}\text { 後遗症, 副作用が少ない } \\
\text { から }\end{array}$ & 1.0 & 3.2 & \\
\hline その他 & 1.6 & 10.5 & \\
\hline 計 & 100.0 & 100.0 & \\
\hline
\end{tabular}


表 5 経由医療機関の分布

\begin{tabular}{|c|c|c|c|}
\hline 医 療 機 関 & 東洋医学 & 西洋医学 & $\dot{x}^{2}$-test \\
\hline 薬局 & 9.7 & 14.7 & \\
\hline 靼医院 & 24.8 & 9.3 & \\
\hline 医院 & 15.0 & 37.8 & $45.725^{* * *}$ \\
\hline 保健所 & 2.4 & 1.3 & \\
\hline 総合病院 & 42.7 & 28.9 & \\
\hline その他 & 5.3 & 8.0 & \\
\hline 計 & 100.0 & 100.0 & \\
\hline
\end{tabular}

表 6 補薬の服用, 医療機関への信頼及び韓方医 学の必要性

\begin{tabular}{|c|c|c|c|}
\hline 区 & 東洋医学 & 西洋医学 & $\chi^{2}$-test \\
\hline \multicolumn{4}{|l|}{ 補薬の服用経験 } \\
\hline ある & 61.5 & 68.5 & \\
\hline ない & 38.5 & 31.5 & 2.119 \\
\hline \multicolumn{4}{|c|}{ 医療機関への信頼 $(+)$} \\
\hline 韓方病(医)院 & 38.3 & 10.6 & \\
\hline 病(医)院 & 8.7 & 15.0 & $45.237^{* * *}$ \\
\hline 薬局 & 2.0 & 2.2 & \\
\hline 大学病院 & 51.0 & 72.2 & \\
\hline \multicolumn{4}{|l|}{ 幹方医学の必要性 } \\
\hline 必要である & 91.2 & 81.8 & \\
\hline 必要ではない & 1.9 & 7.2 & $10.175^{* *}$ \\
\hline わからない & 6.9 & 11.0 & \\
\hline
\end{tabular}

$*$ * $p<0.01$

$* * * p<0.001$

（9.7\%）の順で，一方，西洋医学を利用した者の 場合は医院 (37.8\%), 総合病院 $(28.9 \%)$, 薬局 （14.7\%）の順で, 統計学的に有意の差異がある $(\mathrm{p}<0.001)$.

4）補薬の服用, 医療機関の信頼及び韓方医学の 必要性

表 6 は東洋医学を利用した者と西洋医学を利用 した者の補薬の服用，医療機関の信頼及び韓方医 学に対する必要性について分析した結果額ある。

補薬服用経験の有無に関しては, 東洋医学 (61.5\%), 西洋医学 (68.5\%) であり統計学的に 有意差はなかった（p>0.05）。医療機関の信頼度 を比較した結果, 東洋医学を利用したものが医療
表 7 韓方医療に対する理解度

\begin{tabular}{|c|c|c|c|}
\hline & 東洋医学 & 西洋医学 & $\chi^{2}$-test \\
\hline \multicolumn{4}{|l|}{ 韓方に対する理解度 } \\
\hline 良い & 84.2 & 71.0 & \\
\hline 悪い & 1.4 & 1.3 & $11.739^{*}$ \\
\hline まあまあ & 14.4 & 27.7 & \\
\hline \multicolumn{4}{|l|}{ 韓方が良い理由 } \\
\hline 医療費が安い & 0.0 & 0.5 & \\
\hline $\begin{array}{l}\text { 注射・手術等の苦痛が } \\
\text { ない }\end{array}$ & 16.8 & 25.0 & \\
\hline われわれの医術だから & 50.2 & 44.0 & $14.369^{*}$ \\
\hline 病(医)院で失敗して & 16.2 & 7.0 & \\
\hline その他 & 16.8 & 23.5 & \\
\hline \multicolumn{4}{|l|}{ 韓方が悪い理由 } \\
\hline 医療費が高い & 58.8 & 22.5 & \\
\hline 手術ができない & 19.3 & 25.0 & \\
\hline 信じられない & 5.9 & 10.5 & $28.939^{* * *}$ \\
\hline 非科学的たから & 7.6 & 20.2 & \\
\hline その他 & 13.4 & 21.8 & \\
\hline
\end{tabular}

機関では大学病院 $51.0 \%$, 韓方病（医）院 $38.3 \%$ で，西洋医学を利用した者の場合は大学病院 $72.1 \%$, 病(医)院 $15.0 \%$, 韓方病(医)院は $10.6 \%$ 程度の信頼をして招り，統計学的に有意の差が見 られている $(\mathrm{p}<0.001)$ ，な扰，韓方医学の必要性 に対して東洋医学を利用した者 $(91.2 \%)$ と西洋 医学を利用した者 (81.8\%) が “必要である”と 答えており, 統計学的に有意の差が見られた $(\mathrm{p}<$ 0.01).

5）韓方医療に対する理解度

表 7 は韓方医療に対する理解度の調査結果であ る、韓方に対する理解度については，東洋医学を

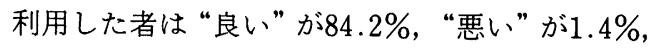
“まあまあ”が $14.4 \%$ で，西洋医学を利用した者は “良い”が71.0\%，“悪い”が1.3\%，“まあまあ” が27.9\%で統計学的な有意差が見られた（p< 0.05)。韓方が良い理由については，“われわれの 医術だから”が50.3\%，“注射・手術等の苦痛がな いから”が $16.8 \%$ で，西洋医学を利用した者が考 える韓方は，“われわれの医術だから良い”が $44.0 \%$, “注射・手術等の苦痛がないから”が $25.0 \%$ 
で統計学的な有意差が見られた $(\mathrm{p}<0.05)$. 反面, 韓方が悪い理由については東洋医学を利用した者 は，“医療費が高い”が53.8\%，“手術ができない” が19.3\%等で, 西洋医学を利用した者が挙げる理 由は“手術ができない”が $25.0 \%$ ，“医療費が高い” が22.5\%，“非科学的だから”が $20.2 \%$ などに示さ れ，統計学的な有意の差が見られた $(\mathrm{p}<0.001)$.

6）韓方医療制度に対する態度

表 8 は韓方医療制度に対する患者の態度を分析 した結果である。東洋医学と西洋医学の統合・分 離運営について，東洋医学を利用した患者たちは “統合運営がよい”が $67.8 \%$, “分離運営がよい” が22.4\%であるのに対し, 西洋医学を利用した者 は54.9\%が統合運営に賛成, $32.3 \%$ が分離運営に 賛成している $(\mathrm{p}<0.05)$ 。なお，分離運営方式の 問題点についての認識では東洋医学利用者は医療 機関間の不信 $(30.5 \%)$, 医療費の二重負担 (25.1\%) 等で, 西洋医学利用者の場合は “選択が むずかしい”(37.4\%), “医療機関間の不信” (34.6\%)，“医療費の二重負担”（18.5\%)である. しかし，この点については両機関利用患者間の態 度の差異は統計学的に有意ではなかった（ $\mathrm{p}<$ 0.05 ).

7）医薬品に対する知識

表 9 は補薬と韓薬に対する両機関利用者の認識 度を調査した結果である，東洋医学を利用した患 者では“韓薬の効果が大きい”が $81.3 \%$,“洋薬が 大きい”はわずか $1.0 \%$ であった。

表 8 韓方と洋方の運営方式に対する意見比較

\begin{tabular}{lrrr} 
& & \multicolumn{2}{r}{ 単位 : \% } \\
\hline & 東洋医学 & 西洋医学 & $\chi^{2}$-test \\
\hline 統合運営に対する意見 & & & \\
分離運営が良い & 22.4 & 32.4 & \\
統合運営が良い & 67.8 & 54.9 & $7.880^{*}$ \\
わからない & 9.8 & 12.8 & \\
分離運営方式の問題点は & & & \\
医療機関間の不信調整 & 30.5 & 34.6 & \\
選択がむずかしい & 39.0 & 37.4 & 3.127 \\
医療費の二重負担 & 25.1 & 18.5 & \\
その他 & 5.4 & 9.5 & \\
\hline
\end{tabular}

${ }^{*} \mathrm{p}<0.05$
表 9 韓薬と洋薬の効果に対する認識度の比較

\begin{tabular}{lrrr} 
& & \multicolumn{2}{r}{ 単位:\% } \\
\hline & 東洋医学 & 西洋医学 & $\chi^{2}$-test \\
\hline 補薬の効果は & & & \\
韓薬が大きい & 81.3 & 72.4 & \\
洋薬が大きい & 1.0 & 4.0 & $6.865^{*}$ \\
場によってちがう & 17.7 & 23.6 & \\
治療薬の効果は & & & \\
韓薬が大きい & 8.7 & 8.4 & \\
洋薬が大きい & 44.4 & 57.5 & $7.612^{*}$ \\
場合によってちがう & 46.9 & 34.1 & \\
\hline${ }^{*} \mathrm{p}<0.05$ & & &
\end{tabular}

西洋医学を利用した者も補薬の効果について “韓薬が大きい”が $72.4 \%$, “洋薬が大きい”は $4.0 \%$ で $(\mathrm{p}<0.05)$ ，両機関を利用した患者たちは韓薬 の補薬効果が大きいと回答した。な拉，治療薬の 効果については, 東洋医学を利用した者の場合, “韓薬が大きい”がわずか $8.7 \%$, “洋薬が大きい” は $44.4 \%$ ，“場合によって違ら”が46.9\%であった。 西洋医学を利用した者の応答結果は治療薬の効果 として“韓薬が大きい”がわずか $8.4 \%$, “洋薬が 大きい” $57.5 \%$ ，“場合によって違う”が34.1\%で あり，両機関を利用した患者たちの治療薬として は洋薬が良かったとなっている $(\mathrm{p}<0.01)$.

\section{IV 考 察}

本研究の調査対象病院は1991年度現在, 韓医科 大学附属病院 (東洋医学) 339 病床と医科大学附属 病院 (西洋医学) 1,014病床で, 病床稼働率は各々 $85 \%$ 程度である。特に韓方病院は全国韓方病院の 総入院患者の $85 \%$ を占めており, 西洋医学病院の 場合は同一診療圏のソウル市内にある, 医科大学 附属病院中の 1 にすぎない。

しかし, この西洋医学病院が他の医科大学病院 に比べて, 特殊な患者層や疾病群をもつものでは なく，韓国における西洋医学病院を代表するもの としてょいと考兄られる。

ICD-9分類によって疾病状態を比較した結果, 西洋医学を利用した患者の場合, 損傷及び中毒が $11.67 \%$ ，循環系疾患が $10.88 \%$ ，そして消化系疾 
患が $10.35 \%$ ，東洋医学を利用した患者の場合， 循環系疾患が70.97\%, 筋骨格系・結合組織疾患が $11.4 \%$ であり,循環系疾患の患者の方が多かった。 したがって西洋医学を利用した患者にくらべて東 洋医学を利用した患者に循環系疾患が多い理由は 表 3 が示すように高年秢の患者たちが多数利用す ることにあると思われる。

質問票を用いた調查は多くの場合, 共通して, ある程度の問題点と限界をもっている。 その中で 代表的な問題点は，1）質問の妥当性，2）質問内 容の社会文化性，3）外国で作成した質問項目の場 合には翻訳の影響である(高，1980)。それにも拘 わらず質問票調査の信頼度は，慎重に実施するな らば少なくともかなりの水準（fair level）以上を 維持できる，患者意識調查は一般に，質問票調査 の信頼度を高めるために補助的な調查によって補 完されれば，信頼度を極大化させることができる (金, 1989)。本研究では東洋医学々西洋医学に対 する患者の受療行動と意識を相互比較するために 質問票調査を直接聞き取り法に重ねて行った。

本研究の成績については，まず東洋医学を利用 した患者たちのうち年齢が高くなるにつれて男性 より女性の利用率が高く現われた。な拉，韓方医 療 (oriental medicine or herb medicine) が西洋 医療 (western medicine or modern medicine) より慢性治療には効果があると信じる韓国民が多 いとする結果は, 既存の研究結果 (Kim ら, 1980, Yang ら，1885)を支持するものである．特に，50 代と60代が全体の50～60\%以上を占めており，こ れも, 朴 (1982), 李 (1978), 及び盧 (1986), 金 (1990), 李ら (1991) の研究と類似の様相を示し ている。この結果は日本の伝統医療利用状況とも 類似している（渡邊ら, 1990, 酒井ら, 1990).

勿論 Evashwick ら (1984)によって医療の利用 は年齢が高いほど男性よりは女性に多いといら報 告があるが特に, 東洋医学は西洋医学にくらべて 年路層が増加するほど高い傾向をあらわしてい る. 東洋医学病院を利用した患者の中で総合病院 を経由してくる患者が $42.7 \%$ みられたよらに (表 5 ), 総合病院で治療が不可能, または総合病
院より韓方病院が治療に効果的であるとして韓方 病院を訪れる場合が考兄られる。補薬服用の経験 は全体の61.5\%以上であった。それは李ら(1991) の研究では, 全体の $70.4 \%$, 男性の経験率の $66.8 \%$ とほぼ同じ傾向であった。調査対象者中の $80 \%$ 以 上が韓方医薬の必要性を提起しており, 今後韓方 薬の研究・開発・普及が要請されるところである. な损，韓方医学に対しても70\%以上が「好い」と 肯定的な意見を示している，以上の理由で韓国の 医術（東洋医学を利用した患者 $50.3 \%$, 西洋医学 を利用した患者 $44.0 \%$ ）が正しいものであると立 証することができたのである。しかしながら，百 余年前無批判的に伝えられた西洋医学々韓国の固 有の医術といえる東洋医学の相互発展に対して保 健・医療界の努力が要求されよう。ところが，東 洋医学は医療費が高とする意見が多い，韓方医学 の医療保険もまた制限的（南ら，1988）なことに より, 保険適用の拡大が要求されなくてはならな いといら一面を持っている，また，手術をする方 法論を持たないこと, 非科学性等の問題も提起さ れ，その補ら方法が要請されるところである。洪 （1979）に依って韓国の韓医師279名を対象に韓方 と洋方の統合可能性に対して設問調査した結果, 統合可能性があるのが $45.1 \%$ で， $52.0 \%$ が不可能 であると解答している研究結果を得た。本研究の 結果, 調查対象患者の $60 \%$ 程度が統合運営を賛成 して扣り医療消費者である患者の方が医療従事者 よりは統合一元化に対しょり多くの賛意を表明す る傾向を示している。

補薬の効果に対しては70\%以上が韓薬, 治療薬 の効果では $50 \%$ 程度が洋薬を支持していた。しか し, 疾病治療の $30 \sim 40 \%$ 程度は場合によって効果 が異なるので韓薬, 洋薬を併用する患者が多かっ たと思われる。韓薬も疾病に対して治療効果が あったと信じる患者が多いといわれている。

以上の東洋医学を利用した患者と西洋医学を利 用した患者の疾病行動研究をした結果, 東洋医学 または西洋医学を利用した患者間の疾病形態は相 異して招り, 受療行為では異なる部分も多いが, 統合の賛成, 補薬には韓薬を, 治療薬には新薬等 
をという選択に対しては同様の考劣を持っている といえる。

\section{V 結 語}

韓国で唯一の同一キャンパス内の医科大学の附 属病院と韓医科大学附属病院を対象に東洋医学々 西洋医学を利用する患者の疾病行動分析を施行 し，次のような結果を得た。疾病の内容分析時医 療院の診察記録簿の統計資料を利用し，患者行動 分析は質問票調査によった。

以上の結果を要約すると以下の通りである.

1. 最近 3 年間に打ける東洋医学を利用した患 者と西洋医学を利用した患者の疾病構造を分析し た結果，ICD-9分類法による入院患者の疾病構造 は西洋医学を利用した患者の場合, 循環系疾患, 筇骨格系及び結締組織の疾患が大部分で, 反面, 西洋医学系利用患者は損傷预よび中毒, 循環系疾 患, 消化系疾患の順であった。東洋医学と西洋医 学を利用した患者の多発性疾患は東洋医学を利用 した患者の場合, 脳梗塞, 脳出血, 一過性脳虚血 性疾患が多く, 西洋医学を利用した患者の場合, 脳梗塞, 糖尿病, 脳出血等が多かった。

2. 東洋医学を利用した患者は男子ょり女子が 多く $(\mathrm{p}<0.05)$, 年齢が増加すればするほど多く なる $(\mathrm{p}<0.001)$. 居住地, 所得, 学歴, 保険種別, 宗教等の変数は統計学的な差異をもたらさなかっ た $(\mathrm{p}<0.05)$.

3. 患者の来院動機に対する東洋医学を利用し た患者は医療スタッフが良い，医療スタッフが有 名，医療機関施設が良いの順であった。西洋医学 を利用した患者は近い，医療機関施設が良い，医 療スタッフが良い等の選択動機順位で（p< 0.001）ある。

経由した医療機関では，東洋医学を利用した患 者の場合, 総合病院, 韓医院, 医院の順で, 西洋 医学を利用した患者は医院, 総合病院, 薬局の順 で, 統計学的に有意差があった $(\mathrm{p}<0.001)$.

4. 補薬服用の経験の有無については, 東洋医学 を利用した患者の $61.5 \%$ 西洋医学を利用した患 者 $68.5 \%$ が服用経験があることであらわれたが,
統計学的な有意差はなかった $(\mathrm{p}<0.05)$.な拉, 韓方医薬にたいする必要性について, 東洋医学を 利用した患者 $91.2 \%$ ，西洋医学を利用した患者の $81.8 \%$ が必要と回答して招り, 統計学的に有意差 があった $(\mathrm{p}<0.001)$ ．そして，補薬の効果につい ては東洋医学を利用した患者 (81.3\%) と西洋医 学を利用した患者 $(72.2 \%)$ と，ともに効果が大 きいと答えているが, 統計学的な有意差があった。 しかし，治療薬の場合には洋薬の方が効果が大き いとの意見が $50 \%$ 以上あった $(\mathrm{p}<0.05)$.

5: 韓方医学については, 東洋医学を利用した患 者の $84.2 \%$, 西洋医学を利用した患者の $71.1 \%$ が 良いと回答して統計学的に有意差があった（p< 0.05). 韓方医学が良い理由はわれらの医術である から，注射・手術等の苦痛がなくて良かったとの 回答であった，

また韓方医学が悪い理由は, 東洋医学利用者で は，医療費が高い，手術ができないとする場合が 多く，西洋医学利用者では手術ができない，值段 が高い，非科学的であるとの回答であり，両医療 機関の利用者間に差異があった $(\mathrm{p}<0.001)$.

6. 韓方と洋方の運営方式について統合運営が よいという回答は，東洋医学を利用した患者に拉 いて $67.8 \%$ ，西洋医学を利用した患者に拈いて 54.9\%であって統計学的に有意差があった。

謝辞：本稿を終えるにあたり，終始ご指導・ご校閲 を賜りました東邦大学の豊川裕之教授に深く感謝致し ます。

\section{文献}

高 應麟，朴 恒培（1980）：韓国人が適用している CMI の健康調査票の信頼性に関する調查研究, 大韓 医学協会誌, 23(1), 55-73

Goldfarb, M.G., Hornbrook, M.C. \& Higgins, C.S. (1983): Determinants of hospital use ; A crossdiagnosis analysis, Medical Care, 21, 48

金 乗益，李 永調，韓 達鮮 (1990)：医療保険適 用人口の医療利用度と加入期間との関係，大韓予防 医学会誌, 23(2)

金 松賢 (1979)：保健要員との接触度と一次健康管 理に対する知識態度及び実践に関する調査研究，7 -9 , 延世大学校保健大学院 (ソウル, 韓国)

Kim, Y.K., Sich, D., Park, T.K. \& Kang, D.H. 
(1980): Naeng-A Kornean folk illness, its ethnography and its epidemiology, Yonsei Medical Journal, 21, 147-155

金 榮俊 (1991)：韓方病医院特性による韓医師の洋 方に対する認識及び態度, 延世大学校保健大学院, 44一46 (ソウル，韓国）

金 馹舜 (1986)：疫学的研究方法, 51-56, 民音社 (ソウル，韓国)

金 馹舜, 李 庸昊, 柳 承欽 (1980)：医療保健実 施前と後の医療利用比較, 大韓保健協会誌, 6(1), 31 $-38$

金 在亭 (1988): 東西医学の接近について, 医林誌, 55一81（ソウル，韓国)

金 重明 (1986)：医史学概論，290-302，螢雪出版 社（韓国）

金 鎮順 (1990) a: 農村地域の韓方医療利用実態, 韓 国農村医学会誌, 15, 5一6

金 鎮順，柳 好信 (1988)：住民の伝統医療利用度 調查研究，韓国人口保健研究院，3-10

金 昌瞱，許 鳳烈 (1989)：設問誌による病歴調查 の信頼度に関する調查研究, 大韓保健協会誌, 15(2), $45-54$

羅 嶺雪 (1990)：度熙医療院附属病院之韓方病院入 院患者の属性に関する考察, 慶熙大大学院碩士論文, 17-18 (韓国)

南銀祐（1988）：北韓の保健医療制度と保健状態， 北韓研究所 (韓国)，12（214），159-160

南 銀祐, 金 基勲（1988）：医療保健の解説，263 -264，高文社（ソウル，韓国）

南 鈴祐, 金 松賢, 南 商堯, 金 敬那(1991)：韓 方医学之西洋医学の一元化の可能性に関する研究, 48-49, 高神大学保健科学研究所 (釜山, 韓国)

盧 承鉉 (1986)：韓方病院の外来患者の実態調査, 東西医学 11(3), 30-39

大塚恭男 (1987)：東洋医学小史, 漢方療法の現況之 新たなる展開, Medical Tribune, 10-11（東京）

大韓病院協会 (1991)：会員病院名薄, 大韓病院協会 (ソウル，韓国)

渡邊正樹, 滝沢利行, 田辺信太郎, 東郷正美 (1990)： 豪雪過疎地域に扣ける住民の保健関連行（特に民間 療法に関する）とその背景，民族衛生，56(4)，184 $-185$

楢木克彦，長島広子，阪野浩司，本多正典，山口啓二 (1991)：慶応義塾大学日中医学交流協会：第 6 次 中国派遣団活動報告，日中医学，5(2)，20-21

Lave, J.R. \& Leinhardt S. (1976): The coslt and length of a hospital stay, Inquiry, 13, 327

Mechanic, D. (1978): Correlates of physician utilization : Why do major multivariate studies of physician utilization find trival psychosocial and organizational effect? J. of Health and Social

Behavior 20(December), 387-396

文 昌真 (1990)：保健医療社会学，新光出版社，90 -91（ソウル，韓国）

朴宗淇 (1979)：韓国の保健財政と医療保険, 76 -77, 韓国開発研究院（ソウル，韓国）

䨿祥秀（1985）：医療利用に影響を及ぼす要因に関す る分析，大韓予防医学会誌，18(1), 14

保健社会部 (1990)：保健社会部統計年譜, 6-10(ソ ウル，韓国）

Brook, R.H. \& Lohr, K.N. (1985): Efficacy, effectiveness, variations and quality: Boundary - crossing research. Medical Care 23, 710

砂原茂一（1990a）：医者と患者と病院と，134-137， 岩波新書

砂原茂一（1990b）：医者と患者と病院と，134-137， 岩波新書

森谷剋久 (1978)：京医師の歴史一日本医学の源流一, 101-102, 講談社現代新書

宋建庸，朴延雨 (1988)：医療保険が医療利用様 相之医療均露にあたえる効果分析，韓国人口保健研 究院論集, 8(1), 73-99

Abraham M. Lilienfield, (1980) : Epidemiology, 3 -4, Oxford University Press (New York)

Aviva P. (1978): Lecture Notes on Medical Statistics ; 40-41, London, Blackwell Scientific Publications

Yang, J.M., Kim, I.S., Yu, S.H., Kim, H.J., Chae, Y. M., Lee, K.Y. \& Sohn, M.S. : Impact of countywide government health insurance demonstration program on health utilization patterns of rural population in Kang Wha, Korea, January ; 40., Institute of Population and Health Services Research, Yonsei Univ., Seoul, Korea

Evashwick, C., Rowe, G., Diehr, P. \& Branch, L. (1984): Factors explaining the use of health care services by the elderly. Health Services Research, 19(3), 357-382

Worcester, R.M. \& Downham, J. (1978): Consumer Market Research Handbook, Van Nostrand Reinhold Company ; 12

柳 承欽 (1990): 医療政策と管理, Kirinwon, 126 -133（ソウル，韓国）

柳 承欽, 李 庸昊, 趙 宇鉉 (1986)：韓国の医療 利用に関寸る研究，大韓予防医学会誌，19(1)， 137 $-145$

柳 承欽, 趙 宇鉉, 朴 鐘淵 (1986)：島嶼地域住 民の医療利用様相とその決定要因，大韓予防医学会 
誌, $20(2), 287-300$

李 圭植，他 (1984)：1983 年度国民医療利用之医療 費に関する調查研究，韓国人口保健研究院，68一69 李 圭植，吳 根植，金 基玉，林 文赫，明 在日， 文 玉綸 (1985)：全国民医療保険実施の為の制度 研究，韓国人口保健研究院，164-165

李 起南 (1978): 園光大漢医科大学附属漢方病院の 来院患者実態調査, 大韓漢医学会誌, 15(1), 35-42

李 龍一, 市 延煥, 南 喆鉉 (1991): 都市地域住 民の韓薬服用実態とその影響を及ぼす要因分析，大 韓保健協会誌，17(1), 32-32

李 知賢 (1979): ソウル市内漢医院の運営に関する 実態調查研究，ソウル大保健大学院（韓国）

鄭京 (1982)：漢医院利用者の医療追求行為に関 する研究, ソウル大保健大学院 (韓国)

鄭 榮一, 金 公鉉, 姜 重泓, 朴烹鍾, 李 主植, 金 秀春 (1991)：韓国医師人力長期需給に関する 研究, 仁済大学校保健大学研究報告書, 20-23（釜 山, 韓国)

酒井亮二, 玉 城悟, 金城芳秀, 相川章子 (1990)：沖 繩住民に扣ける祖先崇拝行動と保健医療行動の関連 性に関する質問紙調査，日本民族衛生学会誌，56(6),
295

蔡 熙周 (1979)：男女高等学校学生達の韓方医学の 知識・態度及び利用に関する調査研究，延世保健大 学院, 33-34 (ソウル, 韓国)

崔 用旻 (1988)：韓国の韓方医療保険制度に関する 研究，39-40, ソウル大保健大学院 (ソウル, 韓国)

Quinn, J.R. (1973) : Medicine and Public Health in the People's Republic of China, U.S. Department of Health, Educaton and Welfare. Public Health Service. National Institute of Health, 158-171

韓国消費者保護院調査部 (1991)：韓方医療保険制度 の運用現況及び利用実態調査，43-45（ソウル，韓 国)

韓 達鮮, 権 純源, 権 純浩, 黄 聖周 (1986)：春 川市民の医療利用様相之関連要因，11-16, 翰林大 学社会医学研究所 (ソウル, 韓国)

洪 庚龽 (1979)：漢医院の医療実態に関する調査研 究, 延世大学保健大学院, 32-34 (ソウル, 韓国)

黄 聖周 (1986)：一部都市地域住民の傷病状態に対 する調査研究，大韓予防医学会誌，19(2), 303-305

（受稿 1992，1１0） 